\title{
Postoje k lidem s postižením v pracovním kontextu ve vztahu ke zkušenosti s nimi
}

\author{
Lucie Procházková
}

Kontakt

Masarykova univerzita

Pedagogická fakulta

Pořící 31a

60300 Brno

prochazkova.lucie@ped.muni.cz

Korespondence:

prochazkova.lucie@ped.muni.cz

Copyright (C) 2019 by the author and publisher, TBU in Zlín.

This work is licensed under the Creative Commons Attribution International License (CC BY).

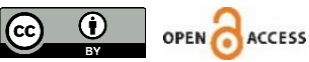

\begin{abstract}
Abstrakt: Otevřenost $k$ začlenění lidí $s$ postižením do společnosti a všech oblastí společenského života je ve velké míře ovlivněna postojem společnosti. Ten se blíže ukazuje i v postojích $v$ dílčích oblastech, jako je například začlenění žáků s postižením do běžných škol či v postojích zaměstnavatelů. $V$ tomto textu jsou představeny výsledky dotazníkového šetření mezi českou populací. Postoj k lidem $s$ postižením zde byl dotazován v obecné šiři, naše pozornost pak byla zaměřena na souvislost s pracovním prostredím. Cílem výzkumu bylo zjistit, zda má zkušenost s člověkem $s$ postižením vliv na jeho akceptaci v pracovním prostředí. Výsledky dokládají pozitivní vliv osobní zkušenosti a poukazují i na rozdíly s ohledem na druh postižení.
\end{abstract}

Klíčová slova: člověk s postižením, postoje, předsudky, obavy, vliv zkušenosti, pracovní začlenění, pracovní prostředí, člověk s postižením jako kolega, teorie kontaktu

\section{Attitudes towards people with disabilities in the work context in accordance with experience of people with disabilities}

\begin{abstract}
Openness to the inclusion of people with disabilities in society and all areas of social life is significantly influenced by the attitude of the population. It is also reflected in attitudes to inclusion in schools and in attitudes of employers. In this paper, the results of a questionnaire survey within the Czech population will be presented. This survey focuses on the influence of experience with people with disabilities to their work integration and their acceptance within the work environment. The results imply that personal contact has a positive influence, and they also show differences according to type of disability and intensity of contact.
\end{abstract}

Keywords: person with disability, attitudes, prejudices, fear, impact of experience, work integration, work environment, person with disability as a colleague, contact theory

\section{1 Úvod}

Mezi hlavní důvody exkluze lidí s postižením z většinové společnosti patří negativní postoje a předsudky vůči těmto lidem, nedostatek informací a povědomí o nich, o jejich schopnostech a možnostech (Kleynhans \& Kotze, 2010). V některých př́padech můžeme hovořit o nezájmu o tuto 
cílovou skupinu. Tyto důvody se zrcadlí do všech oblastí lidského života, včetně oblasti pracovní. Postoje společnosti se v průběhu dějin měnily. Odlišnost dnes už není vnímána jako trest boží, ohrožení a jako něco, co je třeba odstranit a vyloučit. Stále můžeme vnímat nejistotu, obavy, odtažitost, zkreslené představy, na druhou stranu však také otevřenost, snahu o poznání a podporu začlenění a ochotu pomoci. Změna zažitých představ a stereotypů je velmi náročná a trvá dlouho. Bude-li úspěšná, o tom rozhoduje řada faktorů.

Podle WHO (2014) by za exkluzi osob s postižením z trhu práce mohl být odpovědný nedostatečný přístup ke vzdělání a praxi, $\mathrm{k}$ finančním prostředkům, ale také charakter pracovních míst nebo způsob, jakým zaměstnavatelé vnímají postižení a osoby s postižením. WHO podtrhuje nutnost dalších výzkumů o faktorech, které ovlivňuji situaci lidí s postižením na trhu práce.

Velká část lidí nemá osobní zkušenost s lidmi s postižením. Stejně tak ji nemaji i mnozí zaměstnavatelé, ani z pracovního, ani z mimopracovního života. Nemají představu o jejich schopnostech a nedovedou si představit, co by zaměstnání člověka s postižením znamenalo, jak by mohl být tento člověk začleněn do jejich firmy (Hrdá a kol., 2007; Procházková, 2009). Setkáváme se s mylnými či zkreslenými představami o člověku s postižením (Novosad, 2011), s obavami z vysokých nákladů při utváření vhodného pracovního místa (srov. Michálek \& Matysková, 2014; Procházková, 2009) nebo s obavou z nekvalifikovanosti a neproduktivity osob s postižením („WHO“, 2014).

Postoje zaměstnavatelů často reflektují postoj celé společnosti. Otevřený a vstřícný postoj vůči odlišnosti a její vnímání jako obohacení, zaměření na potenciál, na možnosti, a nikoliv jen na nedostatky a překážky je něco, co se v naší společnosti postupně učíme. Před rokem 1989 byli lidé $s$ postižením jen $v$ malé miře aktivními členy naší společnosti. Velké množství z nich bylo od raného věku v institucionálních zařízeních, mnozí $z$ nich v nich strávili celý život. Začlenění na trh práce se nepředpokládalo, neexistovala téměř žádná podpůrná opatření (Procházková, 2014a). Ani ve všedním životě však nedocházelo k takovému kontaktu slidmi spostižením, jako je tomu nyní. Nejen zaměstnavatelé, nýbrž celá česká společnost se tak teprve učí, kdo to je člověk s postižením a jaká je, resp. může být jeho role. Vedle obav a nejistot se tak v posledních desetiletích postupně seznamujeme s touto skupinou lidí, setkáváme se nimi ve všech oblastech našeho života, vnímáme jejich schopnosti, dáváme šance a přiležitosti a utváříme tak nový obraz člověka s postižením.

$\checkmark$ některých aspektech se situace $v$ jiných zemích liší, v jiných nikoliv. Ve Spojených státech amerických např́klad představují lidé s postižením významnou minoritní populaci, v pracovním prostředí však je jejich počet také stále podprůměrný. Jeden z důvodů jejich stále vysoké nezaměstnanosti spatřuje Unger (2002) v negativních postojích potencionálních zaměstnavatelů a spolupracovníků. Kořeny těchto postojů vidí v nedostatku informací o lidech s postižením a v zachovávání chybných stereotypů v jejich posuzování.

Proto jsme se rozhodli nejdřive prozkoumat postoje české společnosti ke kontaktu s lidmi s postižením $v$ pracovním kontextu obecně (stěžejní závěry jsou představeny $v$ tomto textu) a až posléze zaměřit pozornost př́mo na zaměstnavatele.

\section{Postoje společnosti a předsudky}

Lidé jsou otevřenější a vstřícnější vůči věcem, které znají. Neznámé v nich vzbuzuje nejistotu a nervozitu. Stejně tak jsou neznámí lidé vnímáni jako členové určité skupiny, která je cizí (Allport, 2004) a od které by si měl člověk držet odstup. Důsledkem pak mohou být iracionální projevy v postojích a stereotypní chování s předsudky (srov. Unger, 2002; Vágnerová, Hadj-Moussová \& Štech, 2001). Postoj má dva charakteristické znaky: na jedné straně poskytuje usnadnění orientace ve vztahu jedince ke svému okolí, na straně druhé je znakem statutu náležitosti k určité skupině (Nickel, 2019).

Ačkoli může postižení vzniknout z různých přičin a v jakémkoli věku, existuje podle Murphyho (2001) vždy sociální podobnost postižení. Postižení lidé (zde ve smyslu lidé postihnutí postižením) sdílí stejný 
osud, je na ně pohliženo jako na individua, která vybočují ze společenské normy. Postižení má společenský a kulturní význam, představuje sociální chudobu. Postižení přináší člověku znevýhodňující důsledky, které můžou být posilovány bariérami v mezilidských vztazích, architektonickými bariérami či bariérami $v$ dopravě, ale také strachem, nedostatkem informací a postoji plnými předsudků (srov. Novosad, 2011).

Ve společnosti Ize pozorovat dva druhy reakcí na jedince s postižením: fascinaci a s tím související vnímání těchto lidí jako „exotů“ anebo strach a úzkost (Kolářová a kol., 2012). Cloerkes (1985) mluví o dvou druzích sociální reakce: verbálně vyjádřená reakce ve smyslu vnitřního nastavení na základě sociálněpsychologického konceptu o postojích a skutečná reakce v podobě chování vycházejícího $z$ teoretického základu konceptu o stigmatu. Lidé s postižením jsou na jedné straně objektem soucitu, na straně druhé vzbuzují hrůzu a odpor, což může být důsledkem nedostatečné informovanosti lidí okolo. Iracionální a odtažité projevy chování jsou pak výrazem obrany před ohrožením nebo výrazem nejistoty (srov. Vágnerová, Hadj-Moussová, \& Štech, 2001), která se projevuje jak v běžném životě, tak v (ne)ochotě zaměstnat člověka s postižením či jej (ne)akceptovat na pracovišti.

$\checkmark$ české společnosti nebylo po dlouhá desetiletí obvyklé, potkávat osoby s postižením, v práci pak ještě méně. Nedostatek zkušeností spojený s neznalostí pak může, zejména u lidí vyššího věku, vést k ukvapeným závěrům (že lidé s postižením nemůžou vykonávat žádnou práci nebo jen pomocné práce, že většina $z$ nich pracovat ani nechce atp.) a k nevhodným postojům a reakcím.

Postižení je podle Jantzena (1974) v pravém slova smyslu výsledkem společenských podmínek. Postoje $\mathrm{k}$ těmto lidem (zejména $\mathrm{k}$ lidem $\mathrm{s}$ mentálním postižením, autismem či duševním onemocněním) vyjadřují ostatní lidé často nesouhlasem s jejich existencí ve své blízkosti. Dřive se jednalo o umístění institucí, kde tito lidé žili (dř́ve nazývaných ústavy), na okraji města či vesnice nebo v určité vzdálenosti, dnes je to například nesouhlas $s$ budováním chráněného bydlení $v$ sousedství. Podle Kolářové (Kolářová a kol., 2012) jsou obavy, které blízkost mentální odlišnosti vzbuzuje, projevem úzkostného odmítání možnosti, že by se zdravý, racionálně uvažující, soběstačný a autonomní subjekt, s kterým se všichni ztotožňujeme, mohl nějak podobat opaku této představy. Lidé s postižením jsou viditelnou připomínkou toho, že společnost, ve které žijí, je prostoupena nerovností a utrpením, že žijí ve falešném ráji a že i oni jsou zranitelní.

„Největší překážkou v tom, aby se člověk plně zapojil do společenského života, není tělesné postižení, nýbrž mýty, obavy a nedorozumění, které s nimi společnost spojuje“ (Murphy, 2001, s. 95).

Obraz člověka spostižením je v procesu socializace utvářen "chybným povědomím“ naplněným předsudky. Podle Jantzena (1974) je odmítání lidí s postižením úzce spojeno s nízkou zužitkovatelností jejich pracovní síly především v kapitalistických formách hospodářství. „Ten, který může na trhu práce prodat svou (i když nižší) pracovní sílu, má (i když sníženou) pracovní hodnotu; ten, jehož pracovní síla nemá žádnou hodnotu (cenu), nemá sám hodnotu (cenu), ten je považován za ,bezcenný život', za ,nehodného žitíi ", (Jantzen, 1974, s. 159).

Kontakt s lidmi s postižením a zkušenost s nimi přispívají k utváření reálných představ, k překonávání předsudků a k jejich větší akceptaci (srov. Allport, 2004; Procházková, 2009; Unger, 2002). Pozitivní osobní zkušenost s člověkem s postižením se může odrazit i do jeho akceptace v pracovním prostředí (jak z pohledu spolupracovníka, tak z pohledu zaměstnavatele).

Právě v postojích společnosti a postoji zaměstnavatelů vidí lidé s postižením jednu z překážek jejich úspěšného a dlouhodobého začlenění na trh práce (srov. Bělohlávková \& Procházková, 2014; Procházková, 2014b). Podle nich si zaměstnavatelé utváři závěry nebo člověka odmítnou dřiv, než se s ním seznámí a než mu dají šanci představit své znalosti, dovednosti a strategie, jak překonává svá omezení (kterých si jsou tito lidé zpravidla vědomi). Další překážku tvoří pochybnosti o tom, zda jsou lidé s postižením schopni pracovat. Společnost je vnímána jako netrpělivá, nenabízející dostatečnou podporu a tíhnoucí k podceňování lidí s postižením. Práce však má stěžejní význam pro vnímání a utváření vlastní identity. Umožňuje člověku vnímat nejen svá omezení a své postižení, nýbrž vidět v sobě spíš nezávislého a samostatného člověka (Roessler, Hennessey, Neath, Rumrill, \& Nissen, 2011). 


\section{Práce a její význam $s$ bližším zaměřením na jedince s postižením}

Pojem „práce“ označoval dříve takové činnosti, které byly vykonávány každý den (obdělávání pole) a přinášely výdělek. Následně byly zahrnuty i činnosti, které vykonávali řemesIníci. Až mnohem později bylo toto označení přeneseno i na duševní práci, tzv. duševně pracující inteligenci. Nakonec se práce stala životní náplní - bytím (Dasein), které je naplněné prací a zaměstnáním (srov. Hirsch \& Kasper 2010, s. 16).

Práce zaujímá vživotě člověka významnou roli. Je předpokladem pro jeho úplné začlenění do společenského života. Díky práci získávají lidé uznání, možnost seberealizace a lepší kvalitu života, práce dává pocit společenské užitečnosti (srov. Bieker, 2005; Buchtová et al., 2002; Procházková, 2009).

Práci ve smyslu výdělečné činnosti (placená práce) chápe Zwierlein (1997, s. 18) jako „plánovanou, usilovnou a cílenou činnost [...], která primárně slouží k zajištění existence a uspokojení potřeb“. Jahoda (1983) rozlišuje s ohledem na význam výdělečné činnosti dvě funkce: zjevnou a latentní. Zjevnou funkcí práce je zajistit si peníze na živobytí. Latentní (skryté) funkce označují takové funkce, které si člověk většinou neuvědomuje. Patří mezi ně uspokojení základních potřeb, kam spadá i zaměstnání, at si to člověk uvědomuje, nebo ne. Ekonomické zaměření práce je tedy zjevná funkce, smysluplné naplnění dne má naproti tomu latentní (skrytý) význam. Pokud není možné zapojení člověka do výdělečné činnosti, tzn. latentní funkci práce nelze aktivovat, dochází u osob, kterých se to týká, k „psychickému zchudnutí“ (Jahoda, 1983).

Práce umožňuje získávání nových zkušeností a navazování kontaktů mimo rodinu. Dochází k rozšiřování sociální sítě člověka a k podpoře sociálního začlenění. Práce zprostředkovává sociální status a s tím související identitu člověka (Bieker, 2005). Díky dění v práci, zkušenostem a informacím z pracovního prostředí získává člověk nová témata ke komunikaci v tomto i mimo toto prostředí. Tyto aspekty významu práce a zapojení do pracovního procesu se u lidí s a lidí bez postižení neliší.

Pracoviště je místem, kde může člověk podávat výkony, naučit se nové věci a navázat kontakty, kde je brán vážně a má určitou odpovědnost. Pracoviště je tak místem, kde se může i člověk s postižením realizovat (Speck, 2003) a kde jeho hodnota vočích jeho samého i vočích druhých narůstá. Na pracujícího člověka pohliží naše společnost jiným zpưsobem než na lidi nepracující. Práce není jen zdrojem financí, ale také prevencí před sociálním vyloučením, pozitivně ovlivňuje psychiku a posiluje sebevědomí a sebehodnocení. Při práci může člověk uplatnit a ukázat své schopnosti a svůj potenciál, což pozitivně působí na vnímání sebe sama i na vnímání lidmi z okolí a jejich postoje a vnímání celé společnosti. Toto ocenění je pak motivací pro další práci.

Postavením lidí se zdravotním postižením na trhu práce v České republice se ve svém výzkumu zabýval Výzkumný ústav práce a sociálních věcí („VúPSV“, 2014). Tohoto kvantitativního výzkumu se zúčastnilo 2084 osob s postižením ve věku 18-65 let. Jedna oblast otázek byla zaměřena na vnímání hodnoty práce a na aspekty práce, které jsou považovány za důležité. Pro 72 \% respondentů je práce důležitá jako zdroj obživy, pro 62 \% je důležitá vzhledem k možnosti setkávat se s dalšími lidmi. Ve stejné míre (59 \%) pak byla hodnocena možnost "být potřebný/potřebná“ a možnost „nesedět pouze doma“ („VÚPSV“, 2014). Nelze nezmínit, že zaměstnaný člověk s postižením nepředstavuje přínos jen pro něj samotného, nýbrž představuje zásadní přínos i pro naši společnost (z ekonomického i sociálního hlediska). 


\section{Vliv zkušenosti s lidmi s postižením na jejich vnímání v pracovním prostředí a jejich pracovní začlenění}

Při koncipování výzkumného šetření jsme vycházeli z významu pracovního začlenění pro člověka (nejen) s postižením a z obecného postoje naší společnosti, ve kterém Ize pochybnosti ve vztahu k lidem s postižením stále ještě vnímat.

\subsection{Výzkumný cíl}

Cílem výzkumného šetření, které zde představujeme, bylo zjistit, jaký postoj má česká společnost k pracovnímu začlenění lidí s postižením a ke kontaktu s nimi v pracovním prostředí (Procházková, 2014a). Vycházeli jsme ze studií, ve kterých je postoj společnosti vnímán jako významný faktor akceptace a (sociální) participace lidí s postižením. Vhodné postoje vǔči lidem s postižením jsou velmi důležité pro jejich socializaci. Nevstřícný postoj a předsudky mohou vést $\mathrm{k}$ nepřekonatelným bariérám (Speck, 1988).

Postoj společnosti se odráži i do postojů zaměstnavatelů a jejich ochoty zaměstnávat lidi s postižením (srov. Bieker, 2005; Unger, 2002). Nedostatek vlastních nebo zprostředkovaných zkušeností a př́kladů dobré praxe se odráží v postojích zaměstnavatelů, které jak uvádí Bruyère, Erickson a VanLooy (2006), je velmi obtí̌né změnit a otevírají prostor pro předsudky a stereotypy, které jsou s lidmi s postižením spojovány. Ke změně postojů nestačí jen znalost, je zapotřebí i pozitivní kontakt, pozitivní zkušenost (srov. Cloerkes, 1997; Speck, 1988). Zajímalo nás tedy, jestli má osobní zkušenost s člověkem s postižením pozitivní vliv na jeho akceptaci v pracovním prostředí, resp. v pracovním kontextu.

Vlivem kontaktu na chování lidí a vznikem předsudků se zabýval Allport (2004). Vychází z předpokladu, že neznalost vede $k$ mylným, zjednodušujícím a negativním názorům, z nichž pramení nepřátelství a diskriminace.

Zde představené výsledky vznikly na základě analýzy dvou reprezentativních šetření v české populaci, které se zabývaly sociální participací osob s postižením. Jejich cílem bylo zjistit postoje české společnosti $\mathrm{k}$ lidem s postižením v oblasti vzdělávání, práce a sociálních vztahů a ověrit, zda kontakt s nimi a znalosti o nich přispívají k pozitivnějším postojům. Hlavní pozornost ve vyhodnocení těchto šetření byla věnována vzdělávání a procesům školní inkluze (Pančocha, 2013). Pro účely našeho šetření byly vybrány otázky vztahující se k oblasti pracovní. Výsledky byly podrobeny sekundární analýze.

\subsection{Výzkumný soubor}

Výzkumný soubor tvoři obyvatelé České republiky nad 15 let. Byl vybrán náhodným výběrem pomocí kvót. Jeho složení je reprezentativní pro českou populaci nad 15 let vzhledem k pohlaví, věku a regionu (více Pančocha, 2013). Výzkum zahrnuje výsledky dvou šetření, počet respondentů v prvním z nich byl 1797 a ve druhém 1802.

\subsection{Výzkumná metoda}

Data byla sbírána pomocí dotazníkového šetření. $V$ něm byla použita upravená verze Bogardusovy škály sociální distance. Ta je popisována jako ochota jedince zúčastnit se vztahů s různou mírou blízkosti s člověkem, jehož identita je nějakým způsobem stigmatizována (Bogardus, 1947). Dále jsme se opírali o tzv. kontaktní teorii pocházející z myšlenek Allporta (2004). Vyplývá z ní, že kontakt s určitými lidmi nebo skupinou lidí mưže za príznivých podmínek snižovat meziskupinové napětí, úzkost, nepřátelství a předsudky.

Postoje byly zjištovány pomocí Bogardusovy škály sociální distance, ve které respondenti svými odpověd'mi k určitým výrokům vyjadřují míru akceptace ve vztahu k dané skupině. Respondentům v tomto šetření byly pokládány otázky v podobě: „Souhlasili byste s..." nebo „Nevadilo by mi, kdyby..." 
$s$ doplněním určité role daného člověka či prostředí, ve kterém by mělo dojít ke kontaktu, a s ohledem na druh postižení člověka.

Výzkum zohledňoval více úhlů pohledu a zahrnoval několik rovin. Respondenti odpovídali na otázky týkající se akceptace člověka s postižením na pracovišti s ohledem na různé pracovní pozice a pracovní prostředí. Další rovinou bylo zohlednění různých druhů postižení. Respondenti se tak vyjadřovali nejen k akceptování člověka s postižením ve vlastním či jiném pracovním prostředí (např. v roli kolegy), nýbrž i s ohledem na to, jaký druh postižení by daný člověk měl. Tyto výsledky byly následně $v$ další rovině analyzovány vzhledem ke zvoleným proměnným, stěžejní byla existence či neexistence osobní zkušenosti respondenta slidmi s postižením. Dalšími proměnnými byly věk a vzdělání respondentů $\checkmark$ tomto textu bude představena souvislost se zkušeností a věkem respondentů.

S ohledem na druh postižení zjištoval původní výzkum postoje pouze k lidem s tělesným, mentálním a smyslovým postižením. Lidé se zrakovým a sluchovým postižením jsou $v$ něm (ne zcela vhodně) zařazeni do jedné skupiny osob se smyslovým postižením. Toto označení jsme ale zachovali a pracovali $s$ tímto termínem. Uvědomujeme si také, že zaměření pouze na tyto tři skupiny občanů s postižením poskytuje data pouze $k$ těmto třem, resp. čtyřem skupinám osob s postižením (kde smyslové zahrnuje dvě skupiny osob $s$ postižením), nikoliv $k$ celé populaci osob s postižením či zdravotním znevýhodněním. $\vee$ pracovním kontextu totiž velkou část osob s postižením či znevýhodněním představují lidé s tzv. neviditelným postižením. Podle americké Asociace pro osoby s neviditelným postižním (Invisible Disabilities Association) označuje pojem neviditelné postižení (invisible disability) fyzické, mentální a neurologické podmínky, které omezují pohyby, smysly nebo aktivity člověka a které ostatní nevidí. Skutečnost, že přiznaky bývají neviditelné, může vést k nedorozumění, nesprávnému vnímání a nesprávným úsudkům (,„IDA“, 2019). Toto posuzování zdravotního stavu člověka tak kromě jiného může vést i k nesprávnému posuzování jeho práceschopnosti, podceňování závažnosti jeho onemocnění a omezení, která s sebou může přinášet. Patří sem např. lidé s onkologickým, neurologickým či imunologickým onemocněním, lidé s Crohnovou nemocí, epilepsií a řada dalších. Této skupině osob se tento výzkum sice nevěnuje, považovali jsme však za důležité ji zde alespoň zmínit. Výzkum zaměřený na ni by rovněž přinesl zajímavá a př́nosná zjištění.

\section{Výsledky výzkumného šetření}

Naším cílem v tomto výzkumu bylo tedy zjistit, zda má kontakt a osobní zkušenost s lidmi s postižením pozitivní vliv na jejich príijetí v pracovním kontextu (zde se zaměříme na akceptaci člověka s postižením jako kolegy a jako obsluhujícího číšníka, celý výzkum však reflektoval i další role a aspekty). Sledovány byly i rozdíly mezi jednotlivými druhy postižení - tělesné, mentální, smyslové. Následně představíme vyhodnocení hypotéz vztahujících se k výše uvedeným proměnným. K ověřování hypotéz byl využit chí-kvadrát test. Statistické zpracování dat bylo provedeno s využitím softwaru SPSS 21.0. Na základě testování byla provedena interpretace dat a zpracovány grafy.

\section{H1: Kontakt s lidmi s postižením má pozitivní vliv na míru akceptace jejich pracovního začlenění}

Kontakt s lidmi s postižením byl zjištován uzavřenými otázkami, ve kterých respondenti uváděli, zda se setkávají s lidmi s postižením a v jaké oblasti. Nejdřive jsme vyhodnotili, zda ke kontaktu dochází a v jakém prostředí. Hlouběji jsme blízkost kontaktu nezkoumali. Započítáván byl každý kontakt (zkušenost) bez ohledu na to, zda se jedná o blízký vztah (rodina) nebo o vzdálenější vztah (volný čas). Nejvíce zkušeností měli respondenti s lidmi s tělesným postižením $(55,8 \%)$, poté s lidmi se smyslovým postižením (44,5\%) a nejméně s lidmi s mentálním postižením $(35,1 \%)$.

Ve vyhodnocení jsme následně vedle sebe kladli odpovědi od respondentů $s$ a bez zkušeností (viz. Graf 1). Kolegu či kolegyni stělesným postižením by akceptovalo $50,6 \%$ respondentů BEZ zkušenosti a 68,4 \% lidí SE zkušeností. I u lidí se smyslovým postižením je patrný pozitivní vliv existující zkušenosti: akceptaci vyjadřuje 52,7 \% lidí SE zkušeností oproti 37,5 \% lidí BEZ zkušenosti. 
Přijetí člověka s mentálním postižením jako kolegu či kolegyni je celkově nižší, přesto je u lidí SE zkušeností vyšší $(32,1 \%)$ než u lidí BEZ zkušenosti (26,4 \%). Zkušenost se odráží i do odmítavého chování, které je u osob SE zkušeností nižší $(36,5$ \%) než u lidí BEZ zkušenosti $(43,1$ \%).

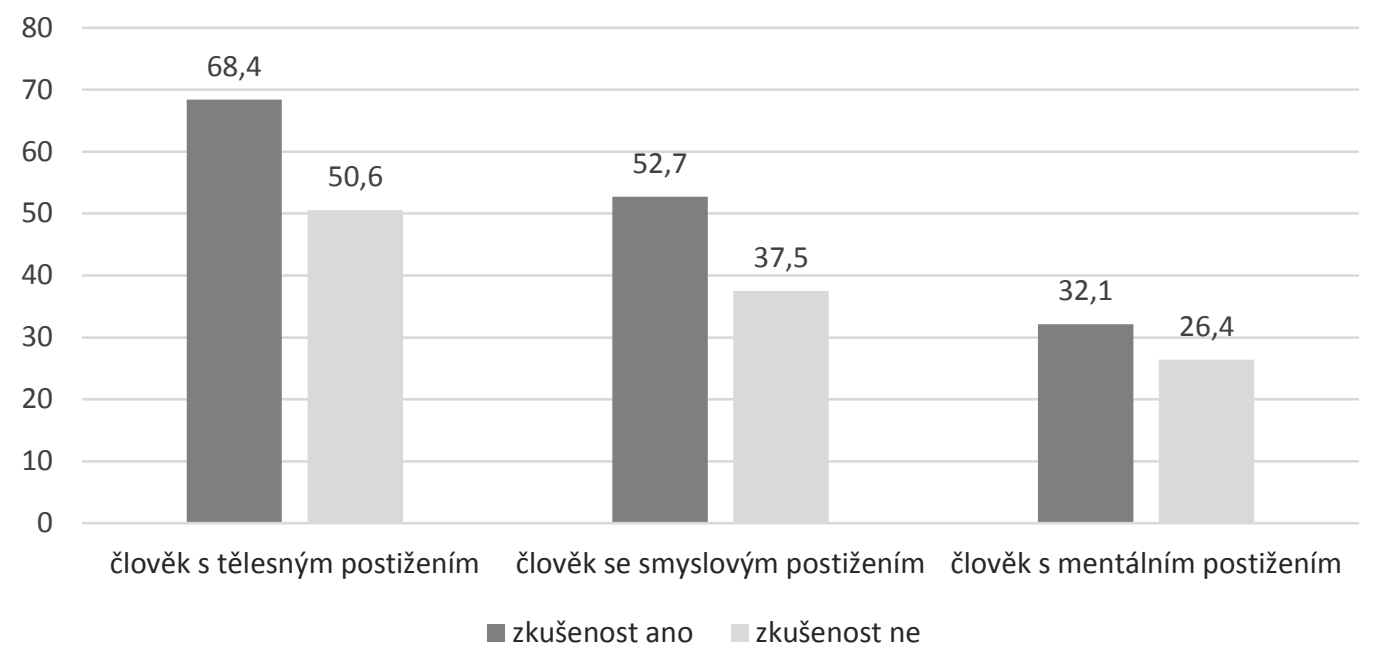

Graf 1. Člověk s postižením jako kolega - vliv zkušenosti

U postoje $\mathrm{k}$ číšníkovi s postižením, který by respondenta obsluhoval, je pozitivní vliv zkušenosti rovněž patrný (viz. Graf 2). Číšníka s tělesným postižením by ve své blízkosti akceptovalo 63,2 \% lidí SE zkušeností s lidmi s postižením (na rozdíl od 50,6 \% těch BEZ zkušenosti), číšníka se smyslovým postižením by akceptovalo 50,2 \% lidí SE zkušeností (na rozdíl od 38,5 \% lidí BEZ zkušenosti). I u lidí s mentálním postižením $v$ roli číšníka Ize pozorovat pozitivní vliv zkušenosti, i když rozdíl není tak markantní jako u ostatních dvou skupin. Akceptovalo by ho 36,1 \% lidí SE zkušeností a 28,5 \% lidí BEZ zkušenosti s lidmi s postižením. Na rozdíl od vztahu $\mathrm{k}$ lidem $\mathrm{s}$ tělesným a smyslovým postižením, u kterých pozitivní postoj jednoznačně převažuje, převládá vưči lidem s mentálním postižením spiše odmítavý postoj.

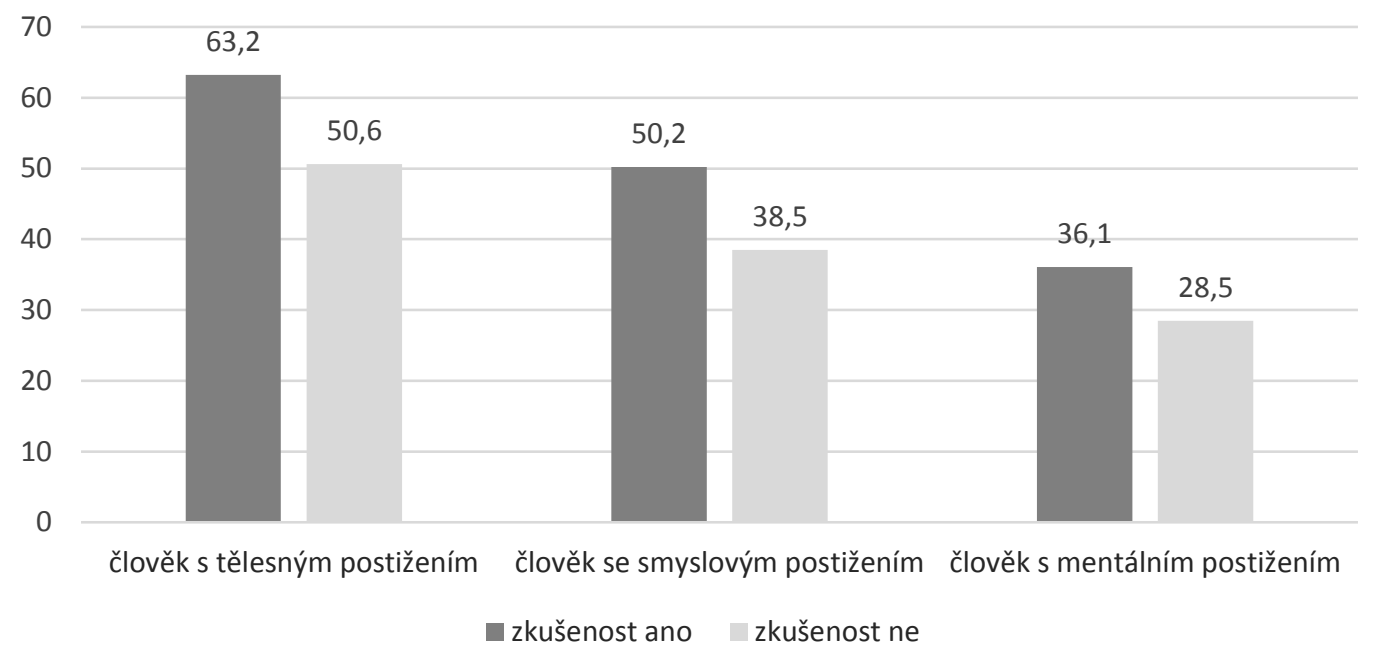

Graf 2. Člověk s postižením jako číšník - vliv zkušenosti

Při ověření hypotézy a analýze jsme nejdříve porovnávali všechny odpovědi s ohledem na existující či neexistující zkušenost. $V$ dalším kroku jsme se zaměřili pouze na odpovědi vyjadřující pozitivní postoj. Při nich byl zaznamenán statisticky významný rozdíl $(p<0,05)$, hypotéza tak byla potvrzena. 
Lidé se zkušeností mají pozitivnější postoj $\mathrm{k}$ lidem s postižením $v$ pracovním prostředí. $\vee$ prípadě akceptace lidí s mentálním postižením je sice patrná převaha odmítavého postoje, se zkušeností se však i tento snižuje.

\section{H2: Věk má vliv na akceptaci člověka s postižením v pracovním prostředí}

Věk byl zjištován pomocí otevřené otázky, ve které respondenti uváděli svůj věk. Odpovědi byly následně seřazeny do věkových skupin: do 35 let, 36-60, 61 a více let. $Z$ výsledků je patrný vliv věku, výraznější je však jen u věkové skupiny nad 61 let. Rozdíl ve věkových skupinách do 35 let a 36-60 jsou pouze v rozmezí 0,6-4,5\%. U lidí nad 61 let je patrná větší skepse vůči setkávání se s lidmi s postižením v pracovním prostředí. I zde je patrný stejný trend jako u ostatních otázek. Nejvíce jsou akceptováni lidé s tělesným postižením, nejméně lidé s mentálním postižením. Ačkoli je míra akceptace člověka s mentálním postižením nejnižší a odmítavý postoj lidí ve věku 61 vyšší než u dalších věkových kategorií, je zajímavé, že v druhém šetření vykazovali nejvyšší míru akceptace lidí s mentálním postižením (v pozici spolupracovníka i jako čišníka) respondenti právě z věkové kategorie nad 61 let. Přesto nepřesahuje 35,6\%.

Věk je proměnnou, která zpravidla ovlivňuje postoje $\mathrm{k}$ lidem s postižením. U starších lidí, kteří prožili většinu svého produktivního života $v$ době, $k d y$ nebylo obvyklé se setkávat $s$ lidmi s postižením a v pracovním prostředí ještě méně, se zpravidla setkáváme $s$ nižší mírou akceptace lidí s postižením ve svém okolí. $V$ tomto šetření se však tato skutečnost ve vztahu $k$ zde zkoumanému pracovnímu kontextu u žádného ze tři zkoumaných typů postižení nepotvrdila (u osob s tělesným postižením $p=0,825$, u osob se smyslovým postižením $p=0,997$, u osob s mentálním postižením $p=0,370$ ).

Ze zjištění z tohoto výzkumného šetření vyplývá, že se předsudky a z nich vyplývající negativní postoje k určité skupině lidí mohou díky kontaktům snižovat. Osobní kontakt a pozitivní zkušenosti s danými skupinami lidí jsou velmi důležité. Domníváme se, že stejný efekt může mít osobní zkušenost s lidmi $s$ postižením na pracovišti. $K$ lidem $s$ tělesným postižením jsou postoje obecně otevřené, u lidí se zkušeností pak ještě vstřícnější. Zaměstnavatelé přesto vyjadřují určité obavy ze zaměstnání člověka s tělesným postižením, jak uvádí Bieker (2005). Patří mezi ně obavy ze snížené výkonnosti, neochota upravit podmínky na pracovišti, nedostatek informací, napětí a odstup při osobní komunikaci s lidmi s tělesným postižením.

Postoj $\mathrm{k}$ lidem s mentálním postižením se díky zkušenosti rovněž mění, ne však tak výrazně. $V$ dnešní době, ve které je na trhu práce kladen důraz na rychlost, výkon a flexibilitu, je pro osoby s mentálním postižením nesnadné, velmi často nemožné těmto požadavkům dostát. Lidé, kteří neodpovídají těmto požadavkům, ze společnosti, resp. z pracovního prostředí vypadávají nebo se do něj vůbec nedostávají. Podle Dedericha (2001) se stávají figurkami na okraji společnosti, které jsou neužitečné, zpưsobují náklady a jsou vnímány jako prítěž.

Postoj k lidem s postižením úzce souvisí s povědomím o nich. U lidí s mentálním postižením je však situace jiná. Ačkoliv povědomí o nich a tolerance $k$ nim postupně narůstají, ne vždy se to projevuje na chování a postojích $\mathrm{k}$ nim. Breitenbach a Ebert (1997) hovoří o změnách, narůstajícím povědomí a snížení předsudků vůči dětem s mentálním postižením, stále silný je však podle nich sociální odstup. $U$ dětí se jedná zpravidla o odstup od rodin s dítětem s mentálním postižením. $U$ dospělých lidí je patrná odtažitost od samotných osob s mentálním postižením, která se odráží v jejich (ne)akceptaci jak v pracovním prostředí, tak i v jiných oblastech života společnosti. Breitenbach a Ebert predstavují situaci na konci 20. stol. Naše šetření ukazuje, že i přes pokračující zlepšení lidé s mentálním postižením i na začátku 21. století stále patří mezi marginalizovanou skupinu. 


\section{Shrnutí a závěr}

Cílem šetření bylo zjistit, do jaké míry ovlivňují zkušenosti s lidmi s různým druhem postižení jejich akceptaci v pracovním kontextu (Procházková, 2014a). Ve studii jsme rozlišovali mezi osobami s tělesným, mentálním a smyslových postižením. Zjištovali jsme, do jaké míry by respondenti souhlasili se spolupracovníkem s daným druhem postižení a s obsloužením od číšníka s daným druhem postižení. Zajímalo nás také, zda se liší postoje ve vztahu k věku respondentů. Druh postižení hraje zásadní roli, jak ukázaly výsledky šetření a značné rozdíly mezi jednotlivými skupinami osob.

Češi se z uvedených tří skupin osob s postižením nejčastěji setkávají s lidmi s tělesným postižením, méně často $s$ lidmi se smyslovým postižením a nejméně s lidmi s mentálním postižením. Nejčastěji se s nimi setkávají ve volném čase (19-28 \%), o něco méně ve škole nebo na pracovišti (11-17\%) a nejméně v rodinném prostředí (3-6\%). Vliv osobní zkušenosti je v postojích k lidem $s$ tělesným a smyslovým postižením jednoznačně patrný. U lidí s mentálním postižením narůstá pozitivní postoj na základě osobní zkušenosti méně výrazně. Lze si však všimnout poklesu odmítavého postoje $k$ těmto lidem, což lze rovněž považovat za významný posun. Ukazuje se však, že pouze běžný kontakt (v jakékoli podobě) není pro trvalou změnu postoje $\mathrm{k}$ lidem smentálním postižením a jejich začlenění do pracovního prostředí dostačující.

Nezbytné jsou zkušenosti ze stejného prostředí. Člověk potřebuje někam patřit, být součástí skupiny, se kterou ho něco spojuje. Potřebuje se s někým identifikovat, někam zapadnout, sdílet obdobné zájmy, přání, zkušenosti i starosti. Během práce mají lidé příležitost poznat jeden druhého z jiného úhlu pohledu, v různých situacích. Na pracovišti všichni plní úkoly, řeší problémy, plánují a rozhodují, komunikují mezi sebou. Někdy je zapotřebí týmová práce, jindy pracuje každý na svém úkolu, v závěru je však poznat, jak je práce každého jednotlivého člověka v celém procesu důležitá. Jedná se o běžné, každodenní situace, při kterých má každý možnost ukázat své dovednosti, silné stránky a svũj potenciál a rozvíjet se. Pracovní tým (zaměstnavatelé, kolegové) pak daného člověka primárně vnímá jako spolupracovníka (zaměstnance, kolegu), nikoliv jako člověka s postižením, a vytváří si tak postoj na základě těchto osobních zkušeností.

Pokud se člověk cítí jako součást týmu, zažívá úspěch, je užitečný, posiluje to jeho sebevědomí a sebedůvěru a narůstá jeho motivace si toto zachovat a na sobě pracovat. Wolfensberger (2001, s. 438) uvádí: "Narůstá-li respekt (image) člověka, pak se zvyšuje i povzbuzení a motivace získávat kompetence." $\checkmark$ tomto se lidé $s$ postižením a lidé bez postižení nijak neliší.

Ve výsledcích šetření jsme zaznamenali rozdíly i s ohledem na prostředí, resp. situace, při kterých se

Osobní zkušenost s lidmi s postižením přispívá k otevřenějšímu a vstřícnějšímu postoji vůči nim. Největší vliv má pozitivní zkušenost a ta, která je postavená na dobrovolnosti. lidé setkávají. Patrná byla vyšší akceptace člověka s postižením v pracovních situacích či prostředí, ve kterém nedochází ke každodennímu kontaktu a k vzájemné spolupráci. Respondenti přijímají člověka s postižením spiše v roli poskytovatele služby (zde číšník), tedy v roli, při které nedochází ke každodennímu kontaktu a při které výkonnost člověka s postižením nijak neovlivní vlastní pracovní nasazení a výkon. U postojů klidem s postižením na stejném pracovišti (kolega) byly výsledky jiné.

Vzhledem $k$ věku respondentů bylo možné $v$ dílčích oblastech pozorovat nižší toleranci $k$ lidem s postižením u starších občanů (nad 61 let), tento postoj však nebyl patrný ve všech oblastech. Obdobný výsledek uvádí Cloerkes (1985) ve své studii. Souvislost mezi věkem respondentů a jejich postojem nebyla v jeho šetření výrazná, nicméně u starších jedinců byla patrná tendence ke spíše odmítavému postoji. 
U starších občanů může být důvodem již dřive uvedený strach z neznámého. Tito lidé se ve svém životě s lidmi s postižením setkávali mnohdy jen zřídka, v pracovním prostředí pak minimálně. Jejich postoj tak může utvářet nejistota $z$ toho, jak se $k$ těmto lidem chovat a jak s nimi komunikovat. Určitou roli můžou hrát i obavy, že daný člověk nebude schopný zvládat svou práci. Respondenti mohou předpokládat, že budou lidé s postižením $v$ práci potřebovat pomoc, která bude je samotné $v$ jejich práci omezovat.

$K$ dosažení změny postoje $\mathrm{k}$ lidem s postižením nestačí pouhá existence nějaké zkušenosti. Domníváme se proto, že by bylo zajímavé zaměřit se dále na jedince, kteří mají pracovní zkušenost slidmi s postižením (zaměstnavatele, kolegy apod.). Na základě skutečných zkušeností ze stejného prostředí jsou zaměstnavatelé či kolegové schopni lépe vnímat a posoudit pracovní schopnosti a kompetence lidí s postižením než někteří respondenti v tomto šetření, kteři uvádí zejména zkušenost $z$ oblasti volného času.

„Rozhodující není četnost kontaktu, nýbrž jeho intenzita. Ne každý intenzivní a úzký kontakt však podporuje pozitivní postoj; důležité jsou i další podmínky, jako je emoční fundovanost a dobrovolnost“ (Cloerkes, 1985, s. 219).

K pozitivnímu postoji či ke změně postoje tak nemusí vést každý kontakt, nýbrž zejména kontakt postavený na dobrovolné bázi a pozitivní zkušenosti. Negativní postoj může být vynuceným prímým kontaktem v některých prrípadech naopak posilován a bariéra mezi těmito lidmi prohlubována.

Osobní zkušenosti přispívají k odbourání předsudků, ke snížení nejistot a k omezení diskriminace. Pozitivní zkušenosti z pracovního prostředí můžou přispět k odstranění znevýhodnění lidí s postižením v pracovním prostředí. $V$ současné době, kdy již lidé s postižením nejsou automaticky vylučováni $z$ většiny oblastí společenského života, kdy se s nimi běžně setkáváme a vnímáme je nejen jako nedílnou součást naší společnosti, ale i jako aktivní a i v pracovní oblasti úspěšné občany, lze očekávat i změnu v postojích české populace směrem k větší otevřenosti, vstřícnosti a ochotě.

\section{Literatura}

Allport, G. W. (2004). O povaze předsudků. Praha: Prostor.

Bělohlávková, K., \& Procházková, L. (2014). Uplatnění osob se zrakovým postižením na trhu práce. In J. Pipeková \& M. Vítková (Eds.), Od inkluze ve školním prostředí k sociální inkluzi a participaci ve společnosti [From school inclusion to social inclusion and participation in society] (s. 257-272). Brno: Masarykova univerzita.

Bieker, R. (Ed.). (2005). Teilhabe am Arbeitsleben. Stuttgart: Kohlhammer Verlag.

Bogardus, E. S. (1947). Measurement of personal-group relations. Sociometry, 10(4), 306-311. https://doi.org/10.2307/2785570

Breitenbach, E., \& Ebert, H. (1997). Verändern Formen schulischer Kooperation die Einstellungen von Schülerinnen und Schülern gegenüber Kindern mit geistiger Behinderung. Behindertenpädagogik, 31(1), 53-67.

Bruyère, S. M., Erickson, W. A., \& VanLooy, S. A. (2006). The impact of business size on employer ADA response. Rehabilitation Counseling Bulletin, 49(4), 194-206.

Buchtová, B. a kol. (2002). Nezaměstnanost. Psychologický, ekonomický a sociální problém. Praha: Grada.

Cloerkes, G. (1997). Soziologie der Behinderten. Eine Einführung. Heidelberg: Universitätsverlag C. Winter.

Cloerkes, G. (1985). Einstellung und Verhalten gegenüber Behinderten - Eine kritische Bestandsaufnahme internationaler Forschung. 3., erweiterte Auflage. Berlin: Carl Marhold Verlag. 
Dederich, M. (2001). Menschen mit Behinderung zwischen Ausschluss und Anerkennung. Bad Heilbrunn: Verlag Julius Klinkhardt.

Hirsch, S., \& Kasper, C. M. (2010). Arbeit - Geschichte eines Handlungsfelds. In G. Grampp, S. Hirsch, C. M. Kasper, U. Scheibner, \& W. Schlummer (Eds.), Arbeit. Herausforderung und Verantwortung der Heilpädagogik (pp. 15-52). Stuttgart: Kohlhammer Verlag.

Hrdá, J. a kol. (2007). Zaměstnávání lidí se zdravotním postižením. Praha: Júš.

IDA - Invisible disability association. How do you define invisible disability? (2019, March 2). Invisible Disabilities $^{\circledR}$ Association. Retrieved from https://invisibledisabilities.org/what-is-an-invisibledisability/

Jahoda, M. (1983). Wieviel Arbeit braucht der Mensch? Arbeit und Arbeitslosigkeit im 20. Jahrhundert. Weinheim: Beltz.

Jantzen, W. (1974). Sozialisation und Behinderung. Gießen: Focus-Verlag.

Kleynhans, R., \& Kotze, M. (2010). Bestuurders en werknemers se houding teenoor persone met fisieke gestremdhede in die werksplek [Managers' and employees' attitudes towards people with physical disabilities in the workplace]. Tydskr. geesteswetvol, 50(3), 404-418.

Kolářová, K. (Ed.). (2012). Jinakost - postižení - kritika. Společenské konstrukty nezpưsobilosti a hendikepu. Praha: SLON.

Murphy, R. F. (2001). Umlčené tělo. Praha: Sociologické nakladatelství.

Michálek, K., \& Matysková, K. (2014, Únor 18). Několik poznámek na téma "nevidomí a práce“. Nevidomí mezi námi. Dostupné $\mathrm{z}$ http://www.nevidomimezinami.cz/main/nmn/Texty/Zamestnani/par_poznamek_na_tema.ht $\mathrm{ml}$

Nickel, S. (2019, March 2). Gesellschaftliche Einstellungen zu Menschen mit Behinderung und deren Widerspiegelung in der Kinder- und Jugendliteratur. Retrieved from http://bidok.uibk.ac.at/library/nickel-einstellungen.html\#idp13959776

Novosad, L. (2011). Tělesné postižení jako fenomén i životní realita. Praha: Portál.

Pančocha, K. (2013). Postižení jako axiologická kategorie sociální participace. Brno: Masarykova univerzita.

Procházková, L. (2009). Podpora osob se zdravotním postižením při integraci na trh práce. Brno: MSD.

Procházková, L. (2014a). Možnosti pracovního uplatnění lidí s postižením - současné trendy v České republice a v zahraničí. Brno: Masarykova univerzita.

Procházková, L. (2014b). Pracovní zkušenosti dospělých osob s tělesným postižením. In M. Hutyrová, E. Souralová, J. Chrastina, \& L. Moudrá (Eds.), Interdisciplinární pohledy na jinakost (s. 269-277). Olomouc: Univerzita Palackého v Olomouci.

Roessler, R., Hennessey, M., Neath, J., Rumrill, P., \& Nissen, S. (2011). The employment discrimination experiences of adults with multiple sclerosis. Journal of Rehabilitation, 77(1), 20-30.

Speck, O. (2003). System Heilpädagogik. Eine ökologische reflexive Grundlegung. 5., neu bearbeitete Auflage. München: Ernst Reinhardt.

Speck, O. (1988). System Heilpädagogik. Eine ökologische reflexive Grundlegung. 1. Auflage. München: Ernst Reinhardt.

Unger, D. D. (2002). Employer's attitudes toward persons with disabilities in the workforce: Myths or realities? Focus on Autism and Other Developmental Disabilities, 17(1), 2-10. 
Vágnerová, M., Hadj-Moussová, Z., \& Štech, S. (2001). Psychologie handicapu. Praha: Karolinum.

VÚPSV. (2014.03.13). Postavení a strategie OZP na trhu práce. Dostupné z http://portal.mpsv.cz/sz/obcane/zamestnavani_ozp/helpforthem/hlavni_vystupy_projektu_a_ jejich_prinosy/dotaznikove_setreni_ozp_na_trhu_prace.pdf

WHO. (2014, March 13). World report on disability. Retrieved from https://www.who.int/disabilities/world_report/2011/report.pdf

Wolfensberger, W. (2011). Social role valorization: A proposed new term for the principle of normalization. Intellectual and Developmental Disabilities, 49(6), 435-440. https://doi.org/10.1352/1934-9556-49.6.435

Zwierlein, E. (1997). Leben ohne Arbeit - Eine Alternative?! In M. Niehaus, \& L. Montada (Eds.), Behinderte auf dem Arbeitsmarkt. Wege aus dem Abseits (pp. 18-27). Frankfurt am Main/New York: Campus. 